\title{
Evaluation of the effects of carbon dioxide pneumoperitoneum on abdominal wall wound healing in rats undergoing segmental resection and anastomosis of the left colon ${ }^{1}$
}

\author{
Avaliação dos efeitos do pneumoperitônio com dióxido de carbono na cicatrização da parede \\ abdominal de ratos submetidos à ressecção segmentar e anastomose no cólon esquerdo
}

\begin{abstract}
Pedro Henrique Alves de Morais ${ }^{\mathrm{I}}$, Igor Eduardo Caetano de Farias ${ }^{\mathrm{I}}$, Leonardo de Castro Durães ${ }^{\mathrm{II}}$, Fabiana Pirani Carneiro ${ }^{\mathrm{III}}$, Paulo Gonçalves de Oliveira ${ }^{\mathrm{Iv}}$, João Batista de Sousav

IGraduate student, Medical School, UnB, Brasilia-DF, Brazil Acquisition, interpretation of data and writing of the manuscript.

"Fellow PhD degree, Postgraduate Program in Medical Sciences, Medical School, UnB, Brasilia-DF, Brazil. Acquisition and interpretation of data.

IIIAssociate Professor, Pathology, Medical School, UnB, Brasilia-DF, Brazil. Acquisition, interpretation of data and critical revision.

${ }^{\mathrm{IV}}$ Associate Professor, Clinical Surgery, Medical School, UnB, Brasilia-DF, Brazil. Statistical analysis, interpretation of data and critical revision.

vAssociate Professor, Clinical Surgery, Medical School, UnB, Brasilia-DF, Brazil. Responsible for conception, design of the study, intellectual and scientific content of the article, analysis, interpretation of data, manuscript writing and critical revision.
\end{abstract}

\begin{abstract}
PURPOSE: To evaluate the influence of carbon dioxide pneumoperitoneum on abdominal wall wound healing in rats.

METHODS: Eighty rats underwent laparotomy, segmental left colon resection, and anastomosis. The animals were divided into three experimental groups and one control group: $\mathrm{EI}=$ pneumoperitoneum for 30 minutes before laparotomy ( $\mathrm{n}=20$ ); EII = pneumoperitoneum for 30 minutes after abdominal closure $(n=20)$; EIII = pneumoperitoneum for 30 minutes before laparotomy and 30 minutes after abdominal closure $(\mathrm{n}=20) ; \mathrm{C}=$ control group, without pneumoperitoneum $(\mathrm{n}=20)$. In each group, 10 animals were killed 7 days and 10 animals 14 days postoperatively. A segment of the abdominal wall was resected and subjected to tensile strength testing. Another segment of abdominal muscle was used for histopathological analysis; the specimens were fixed in formalin and stained with hematoxylin and eosin.

RESULTS: There were no differences in histopathology and tensile strength values among animals in the experimental and control groups 7 or 14 days after surgery.

CONCLUSION: Under the present experimental conditions, carbon dioxide pneumoperitoneum did not interfere with abdominal wall wound healing.
\end{abstract}

Key words: Abdominal Wall. Wound Healing. Pneumoperitoneum, Artificial. Tensile Strength. Rats.

\section{RESUMO}

OBJETIVO: Avaliar a influência do pneumoperitônio com dióxido de carbono na cicatrização da ferida operatória na parede abdominal de ratos.

MÉTODOS: Oitenta ratos foram submetidos à laparotomia, ressecção de segmento do cólon esquerdo e anastomose. Os animais foram distribuídos em quatro grupos de 20 ratos, três experimentais e um controle: Grupo EI = pneumoperitônio por 30 minutos antes da laparotomia. Grupo EII = pneumoperitônio por 30 minutos após a laparorrafia. Grupo EIII = pneumoperitônio por 30 minutos antes da laparotomia e 30 após a laparorrafia. Grupo $\mathrm{C}=$ controle, sem pneumoperitônio. Realizou-se, em cada grupo, a eutanásia de 10 animais no $7^{\circ}$ e no $14^{\circ}$ dia pós-operatório. Um segmento da parede abdominal foi ressecado e submetido à medida da resistência. Outro segmento muscular abdominal foi destinado à análise histopatológica, as peças foram fixadas em formol e as lâminas coradas com hematoxilina e eosina.

RESULTADOS: Não houve diferença, à histopatologia e na força de ruptura, entre os animais dos grupos experimentais e do controle no $7^{\circ}$ ou $14^{\circ}$ dia pós-operatório.

CONCLUSÃO: Nas condições em que o experimento foi realizado, o pneumoperitônio com dióxido de carbono não interferiu na cicatrização da parede abdominal.

Descritores: Parede Abdominal. Cicatrização. Pneumoperitônio Artificial. Resistência à Tração. Ratos. 


\section{Introduction}

Wound dehiscence and incisional herniation of the abdominal wall are potential complications associated with surgical procedures that require access to the abdominal cavity via open surgery or converted laparoscopic surgery. These are also recurrent complications of poorly healing wounds. Patients undergoing laparoscopic ventral hernia repair have fewer postoperative complications, such as wound infections, postoperative gastrointestinal atony, wound dehiscence, and intraperitoneal abscesses ${ }^{1,2}$.

Laparoscopic surgery is a minimally invasive procedure that requires the use of pneumoperitoneum to provide adequate surgical exposure and to enable good visualization and manipulation of the target organ. Carbon dioxide $\left(\mathrm{CO}_{2}\right)$ has been widely used in this procedure, being insufflated into the abdominal cavity to create a pneumoperitoneum, because it is easily excreted, does not support combustion, and is inexpensive. In addition, $\mathrm{CO}_{2}$ is highly soluble in blood and diffuses into the tissues, thus decreasing the risk of gas embolism ${ }^{3}$.

The laparoscopic method allows the performance of procedures with reduced operating time, reduced pain, and early recovery after surgery. Furthermore, laparoscopy is associated with fewer postoperative complications, compared to traditional open surgery, and reduced inflammatory response, thus allowing patients to resume their professional and routine daily activities sooner if no surgical complications occur ${ }^{1-6}$. In addition to these advantages, pneumoperitoneum has been associated with less tumor growth due to surgical stress, in gastric cancer, in relation to open surgery. ${ }^{4}$ Despite all the benefits, laparoscopic surgery is still a more expensive alternative. ${ }^{6}$

Although $\mathrm{CO}_{2}$ pneumoperitoneum induces pathophysiological changes in the kidneys, spleen, and endocrine, cardiovascular, hemodynamic, and pulmonary systems, most changes have a transient effect and no clinical significance in the great majority of cases. The effects produced by pneumoperitoneum depend on the amount of $\mathrm{CO}_{2}$ absorbed, intra-abdominal pressure, circulatory volume status, and prior medical conditions of each patient $^{3,5,6}$.

The magnitude of the pathophysiological effects of pneumoperitoneum on different organs is highly influenced by intra-abdominal pressure, and the maintenance of pressure levels $\leq 12 \mathrm{mmHg}$ in humans induces minimal effects ${ }^{3,5}$. However, pressures above $15 \mathrm{mmHg}$ increase $\mathrm{CO}_{2}$ absorption and the risk of gas embolism ${ }^{5}$. An intra-abdominal pressure of $5 \mathrm{mmHg}$ in Wistar rats has been used to experimentally reproduce pathophysiological changes that occur in humans at a pressure of $12 \mathrm{mmHg}^{7}$.

The objective of this study was to evaluate the influence of $\mathrm{CO}_{2}$ pneumoperitoneum on abdominal wall wound healing in rats undergoing segmental resection and anastomosis of the left colon.

\section{Methods}

This study was conducted at the Laboratory of Experimental Surgery, Medical School, University of Brasilia, Brazil. All procedures were performed in accordance with the guidelines of the Brazilian Committee on Animal Research and Ethics. The study protocol was approved by the Animal Care and Use Committee of the Institute of Biological Sciences, University of Brasilia, Brazil.

Eighty male Wistar rats, with mean initial body weight of $344.98 \mathrm{~g}$ and about 90 days of age, were used in the study. The animals were kept in an animal housing facility with natural ventilation and were given free access to a balanced chow diet and water.

\section{Experimental design}

The animals were randomly divided into four groups of 20 animals each, three experimental groups (EI, EII and EIII) and one control group, as follows:

EI - pneumoperitoneum for 30 minutes immediately before laparotomy.

EII - pneumoperitoneum for 30 minutes immediately after abdominal closure.

EIII - pneumoperitoneum for 60 minutes, 30 minutes before laparotomy and 30 minutes after abdominal closure.

$\mathrm{C}$-Control group, without pneumoperitoneum induction. In each group, 10 animals were killed 7 days (EI7, EII7, EII7, and C7) and 10 animals 14 days (EI14, EII14, EIII14, and C14) postoperatively.

\section{Surgical procedure}

The animals were anesthetized with xylazine hydrochloride at a dose of $10 \mathrm{mg} / \mathrm{kg}$ of body weight, combined with ketamine hydrochloride at a dose of $75 \mathrm{mg} / \mathrm{kg}$ of body weight, intramuscularly. Adequate anesthesia was verified by the absence of withdrawal reflex to painful pinch stimuli, and an additional dose of anesthetics was administered in cases of anesthetic recovery. 
Pneumoperitoneum was induced using a laparoscopic insufflator. After abdominal puncture using a Veress needle, $\mathrm{CO}_{2}$ was insufflated at a flow rate of 0.5 to 1.0 liter per minute, without preheating, to establish pressure at $5 \mathrm{mmHg}$.

Before surgical intervention, animals were weighed, anesthetized, and then fixed in supine position at their thoracic and abdominal limbs on a surgical board. Trichotomy of the anterior abdominal wall was performed, and polyvinylpyrrolidone iodine was used for skin antisepsis.

The surgical procedure consisted of a midline incision of the abdominal wall of about $5 \mathrm{~cm}$. In all animals $1 \mathrm{~cm}$ of the left colon was resected approximately 2.5 to $3.5 \mathrm{~cm}$ proximal to the peritoneal reflection, followed by coloanal reconstruction with end-to-end anastomosis, using running 6-0 polypropylene sutures, whole plane.

The abdominal wall was closed with running 5-0 polypropylene sutures, with approximation of the aponeurosis and muscles. Skin incisions were closed using running 5-0 polypropylene sutures. All procedures were performed by one surgeon.

As previously scheduled, seven and 14 days after surgery, the animals were anesthetized and two samples were obtained from the anterior abdominal wall containing the surgical wound in the central portion: one specimen for histopathological analysis and the other for tensile strength testing. Finally, the inferior vena cava was punctured and the animals were killed with an overdose of thiopental.

\section{Tensile strength}

Tensile strength was measured in newton $(\mathrm{N})$ using a VersaTest test stand (Mecmesin VersaTest, United Kingdom) fitted with a digital force gauge with force capacity of $2500 \mathrm{~N}$ (Mecmesin AFG 2500N, United Kingdom). A rectangular, skinless sample of the abdominal wall, about $1.0 \mathrm{~cm}$ wide, was fixed to the force gauge and subjected to tension at a speed of $25 \mathrm{~mm} /$ minute (Figures 1 and 2).

During tensile strength testing, the specimens were carefully placed and fixed in the test apparatus, with standardization of the distance between the surgical scar and the fixing clamps.

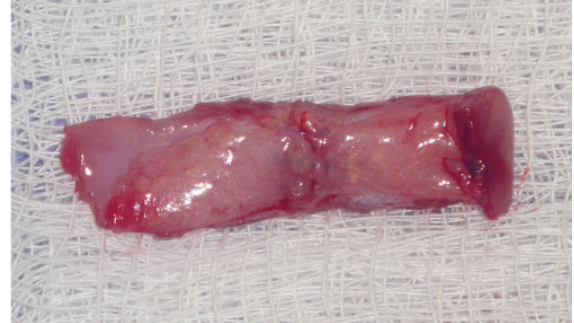

FIGURE 1 - Sample of the abdominal wall used for measurement of tensile strength, with suture in the central portion.

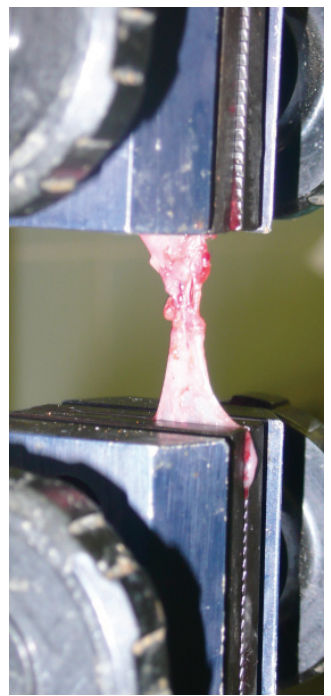

FIGURE 2 - Sample of the abdominal wall subjected to tension for measurement of tensile strength.

\section{Histopathology}

For histopathological analysis, the specimens were fixed in formalin, stained with hematoxylin and eosin, and examined under an optical microscope. The amount of collagen, fibroblasts, polymorphonuclear and mononuclear infiltration and neovascularization was analyzed and graded as 0,1 , or 2 ; with 0 indicating absence of the analyzed parameter, 1 indicating an average amount, and 2 for the samples with the highest amount of the analyzed factor. The presence or absence of abscess, bacterial colony, or foreign body was also analyzed.

The histopathologist examining the slides was blind to which group or subgroup the specimens belonged.

\section{Weighing}

Body weight variations between the day of surgery and reoperation were also analyzed in this study. Body mass was measured using a precision scale ( 0.01 grams resolution). 


\section{Statistical analysis}

The Statistical Package for the Social Sciences (SPSS), version 13.0, was used for data analysis. The Kruskal-Wallis test was used to evaluate tensile strength values, Fisher's exact test to analyze histopathological data, and the Student $t$ test to compare body weight. Significance level was set at $5 \%(p<0.05)$.

\section{Results}

Four animals died during the study: one animal in the $\mathrm{C} 7$ group and three animals scheduled for euthanasia 14 days after surgery (two in EI14 group and one in EIII14 group). Therefore, the sample for final evaluation included 76 animals.

Body weight variation of animals, according to the day of euthanasia, is shown in Table 1.

The mean preoperative body weight of all animals was 350.48 g. Animals killed 7 days after surgery showed a significant weight loss. The mean body weight of animals killed 7 days postoperatively was $355.97 \mathrm{~g}$ before surgery and $331.54 \mathrm{~g}$ at day 7 $(\mathrm{p}<0.001)$. Animals killed 14 days after surgery gained weight in relation to the day of surgery, with mean body weight of $344.70 \mathrm{~g}$ before surgery and $354.57 \mathrm{~g}$ at day $14(\mathrm{p}=0.001)$.

TABLE 1 - Body weight in grams (g) at surgery and 7 and 14 days postoperatively (minimum and maximum values, median, mean and standard deviation).

\begin{tabular}{|c|c|c|c|c|}
\hline \multicolumn{2}{|c|}{7 days after surgery } & \multicolumn{3}{|c|}{14 days after surgery } \\
\hline & $\begin{array}{l}\text { Preoperative } \\
\text { body weight }\end{array}$ & $\begin{array}{c}\text { Body weight } \\
\text { at day } 7\end{array}$ & $\begin{array}{l}\text { Preoperative } \\
\text { body weight }\end{array}$ & $\begin{array}{c}\text { Body weight } \\
\text { at day } 14\end{array}$ \\
\hline Number of animals & 39 & 39 & 37 & 37 \\
\hline Maximum & 402.00 & 377.00 & 397.00 & 429.00 \\
\hline Minimum & 318.00 & 285.00 & 312.00 & 273.00 \\
\hline Mean & 355.97 & 331.54 & 344.70 & 354.57 \\
\hline Median & 355.00 & 337.00 & 334.00 & 349.00 \\
\hline Standard deviation & 19.77 & 27.52 & 25.32 & 29.70 \\
\hline
\end{tabular}

The main data on tensile strength (minimum and maximum values, median, mean and standard deviation) are shown in Table 2. The mean tensile strength of the abdominal wall of animals killed 7 and 14 days postoperatively was 6.38 and 8.17 $\mathrm{N}$, respectively, with statistically significant difference $(\mathrm{p}=0.001)$ (Table 2 and Figure 3 ).
TABLE 2 - Tensile strength (TS) of the abdominal wall in Newton (N) of animals killed 7 and 14 days after surgery (minimum and maximum values, median, mean and standard deviation).

\begin{tabular}{c|c|c}
\hline & $\begin{array}{c}7 \text { days after } \\
\text { surgery }\end{array}$ & $\begin{array}{c}14 \text { days } \\
\text { after surgery }\end{array}$ \\
\hline Number of animals & 39 & 37 \\
Maximum & 14.26 & 14.93 \\
Minimum & 1.82 & 4.10 \\
Mean & 6.38 & 8.17 \\
Median & 5.84 & 7.80 \\
Standard deviation & 2.73 & 2.21 \\
\hline
\end{tabular}

TS at day $7<$ TS at day $14(\mathrm{p}=0.001)$.

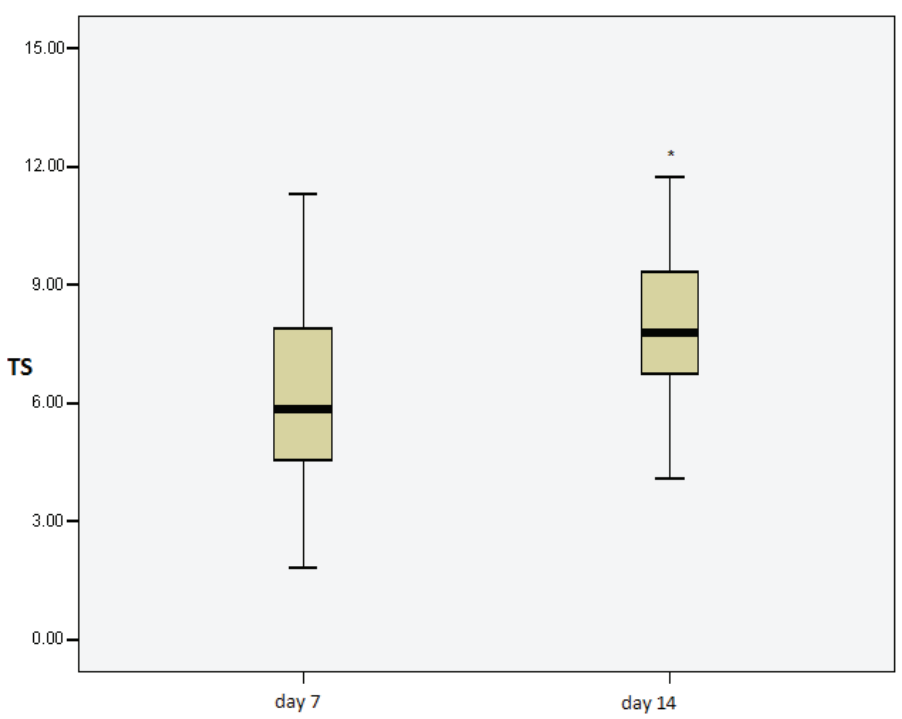

FIGURE 3 - Tensile strength (TS) of the abdominal wall in Newton (N) of animals killed 7 and 14 days after surgery $(p=0.001)$.

There was no statistically significant difference in tensile strength between experimental groups (EI, EII, EIII) and the control group $(C) 7$ days after surgery $(p=0.712)$. Likewise, there was no statistically significant difference in tensile strength among the four groups 14 days after surgery $(p=0.580)$ (Table 3 and Figure 4). 
TABLE 3 - Tensile strength (TS) of the abdominal wall in Newton (N) for the four study groups (EI, EII, EIII, C) 7 and 14 days after surgery (minimum and maximum values, median, mean and standard deviation).

\begin{tabular}{c|c|c|c|c|c|c|c|c}
\hline \multicolumn{7}{c|}{7 days after surgery } & \multicolumn{7}{|c}{ 14 days after surgery } \\
\hline & C & EI & EII & EIII & C & EI & EII & EIII \\
\hline & & & & & & & & \\
Number of animals & 9.00 & 10.00 & 10.00 & 10.00 & 10.00 & 8.00 & 10.00 & 9.00 \\
Maximum & 14.26 & 10.36 & 11.32 & 9.51 & 14.93 & 11.00 & 11.75 & 10.94 \\
Minimum & 1.82 & 3.94 & 3.35 & 2.04 & 5.43 & 4.86 & 4.10 & 6.49 \\
Mean & 6.85 & 6.63 & 6.58 & 5.50 & 9.00 & 7.70 & 7.98 & 7.86 \\
Median & 6.73 & 6.23 & 5.67 & 5.42 & 8.32 & 7.45 & 7.36 & 7.65 \\
Standard deviation & 3.78 & 2.22 & 2.71 & 2.72 & 2.64 & 2.27 & 2.44 & 1.27 \\
\hline
\end{tabular}

$\mathrm{EI}=$ pneumoperitoneum for 30 minutes before laparotomy; EII = pneumoperitoneum for 30 minutes after abdominal closure; EIII = pneumoperitoneum for 30 minutes before laparotomy and 30 minutes after abdominal closure; $\mathrm{C}=$ control group, without pneumoperitoneum.

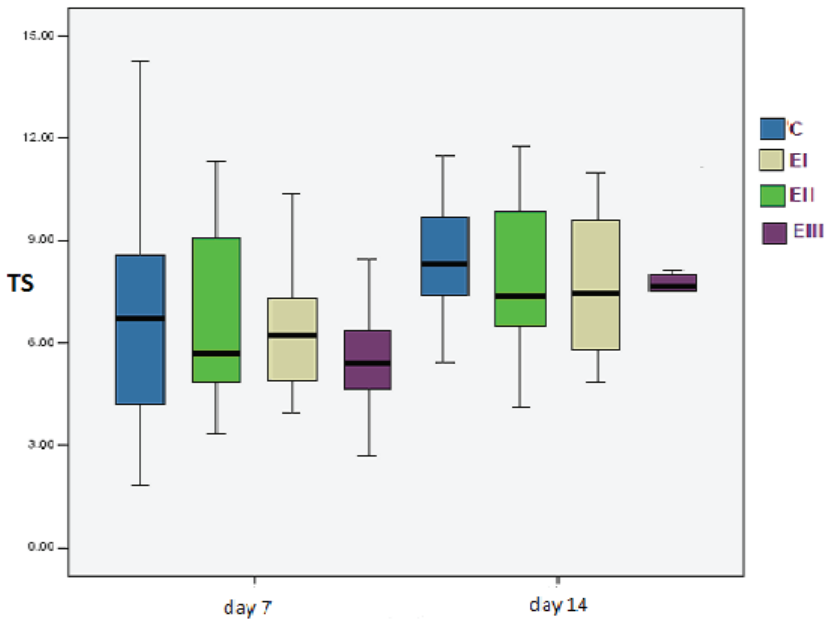

FIGURE 4 - Tensile strength (TS) of the abdominal wall in Newton (N) for the four study groups (EI, EII, EIII, C) 7 and 14 days after surgery.

The histopathological analysis revealed no statistically significant difference among animals killed 7 days postoperatively regarding collagenous tissue $(p=0.188)$, fibroblasts $(p=0.450)$, mononuclear infiltrate $(\mathrm{p}=0.170)$, polymorphonuclear infiltrate $(\mathrm{p}=0.349)$, neovascularization $(\mathrm{p}=0.93)$, abscess $(\mathrm{p}=0.265)$, bacterial colony $(\mathrm{p}=1.000)$, and foreign body $(\mathrm{p}=0.526)$ (Table $4)$.

Similarly, no statistically significant difference was observed among animals killed 14 days after surgery regarding collagen $(p=1.000)$, fibroblasts $(p=0.173)$, mononuclear infiltrate $(\mathrm{p}=0.860)$, polymorphonuclear infiltrate $(\mathrm{p}=0.444)$, neovascularization $(\mathrm{p}=0.206)$, abscess $(\mathrm{p}=1.000)$, bacterial colony $(p=1.000)$, and foreign body $(p=0.231)($ Table 5$)$.

\section{*Tables 4 and 5 on next page.}

\section{Discussion}

The present study investigated possible effects of $\mathrm{CO}_{2}$ pneumoperitoneum by experimentally using pressures equivalent to those used in laparoscopic surgery in humans. Four conditions were established in rats in order to simulate those occurring in surgical practice: preoperative pneumoperitoneum; postoperative pneumoperitoneum; pre and postoperative pneumoperitoneum; and laparotomy without pneumoperitoneum (control).

Preoperative pneumoperitoneum aimed to simulate a situation in which surgery begins with laparoscopy, but requires a switch to laparotomy. According to reports on laparoscopic ventral hernia repair, $7.69 \%$ of the procedures required a switch to open surgery due to complications ${ }^{2}$.

Postoperative pneumoperitoneum mimics a situation in which, after open surgery, during the postoperative period, there is a need to approach the peritoneal cavity and exploratory laparoscopy is the option adopted.

Pre and postoperative pneumoperitoneum is consistent with a common situation observed in colorectal surgical practice in which laparoscopic colectomy, in most cases, is performed using a hybrid approach or there is a need to open the abdominal wall to remove the surgical specimen. In this situation, laparoscopic procedures often require a small laparotomy, thus leaving a surgical wound in the abdominal wall.

In our study, the weight of the animals decreased significantly within 7 days of surgery. However, the weight of animals analyzed 14 days postoperatively shows a complete reversal of this catabolic process based on the significant weight gain observed on day 14. These data replicate those reported in the relevant literature describing that weight loss occurring in the postoperative period is recovered after the 7 th postoperative day ${ }^{8,9}$.

The most commonly used parameters to evaluate the healing process include clinical assessment of animals, tensile strength, analysis of anti-inflammatory activity, collagenous tissue expressed by hydroxyproline concentration or morphometric analysis, and histopathological analysis using optical microscopy ${ }^{10-12}$. Among these parameters, measurement of tensile strength is particularly relevant in cases of intervention through the abdominal wall, because tensile strength testing provides accurate and prompt results and reflects the reality of clinical practice, in which a pulling force is exerted on the surgical wound whenever patients contract their abdomen ${ }^{9,11,13}$.

Histopathological and tensile strength abnormalities Cont.: page 69 
TABLE 4 - Values of histopathological analysis in groups of animals killed 7 days after surgery.

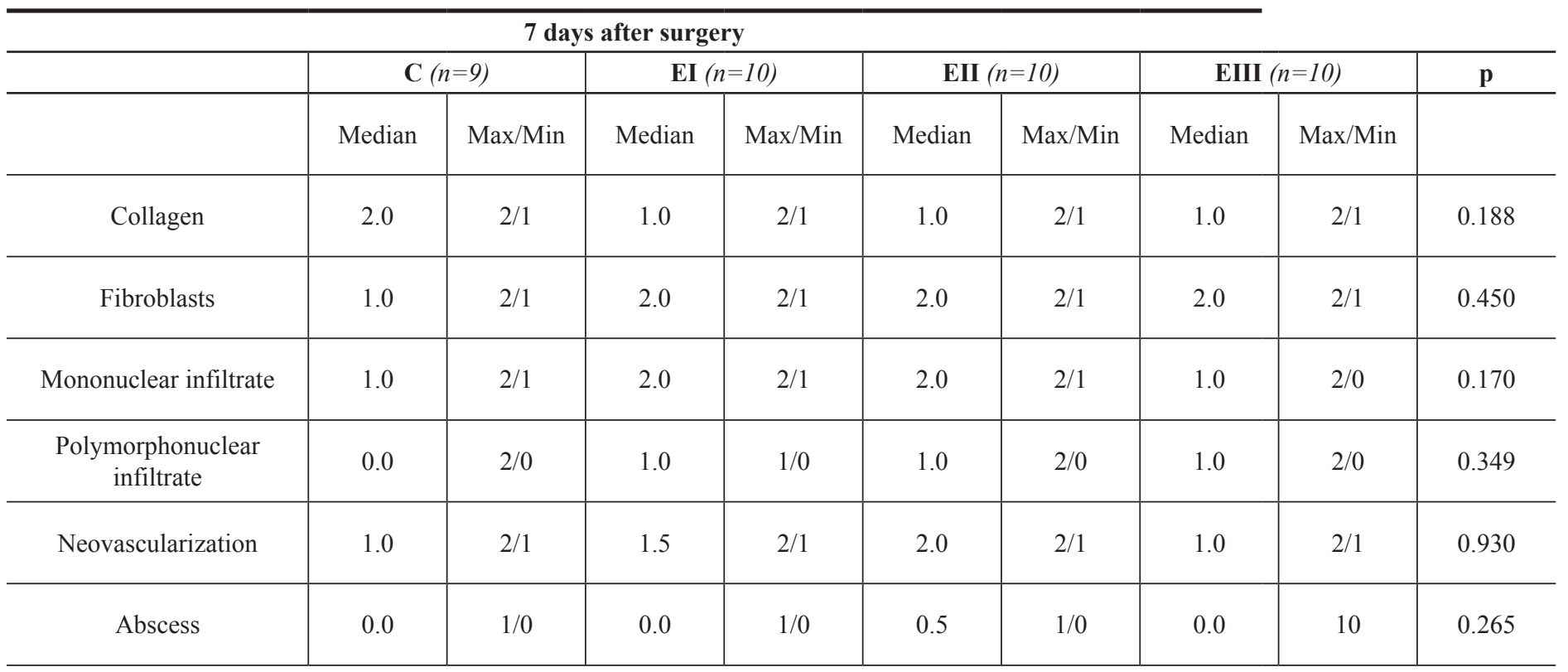

$\mathrm{EI}=$ pneumoperitoneum for 30 minutes before laparotomy; $\mathrm{EII}=$ pneumoperitoneum for 30 minutes after abdominal closure; EIII = pneumoperitoneum for 30 minutes before laparotomy and 30 minutes after abdominal closure; $\mathrm{C}=$ control group, without pneumoperitoneum.

TABLE 5 - Values of histopathological analysis in groups of animals killed 14 days after surgery.

\begin{tabular}{|c|c|c|c|c|c|c|c|c|c|}
\hline \multicolumn{10}{|c|}{14 days after surgery } \\
\hline & \multicolumn{2}{|c|}{$\mathbf{C}(n=10)$} & \multicolumn{2}{|c|}{$\mathbf{E I}(n=8)$} & \multicolumn{2}{|c|}{ EII $(n=10)$} & \multicolumn{2}{|c|}{ EIII $(n=9)$} & \multirow[t]{2}{*}{$\mathbf{p}$} \\
\hline & Median & Max/Min & Median & Max/Min & Median & Max/Min & Median & Max/Min & \\
\hline Collagen & 2.0 & $2 / 2$ & 2.0 & $2 / 2$ & 2.0 & $2 / 2$ & 2.0 & $2 / 2$ & 1.000 \\
\hline Fibroblasts & 1.5 & $2 / 1$ & 1.5 & $2 / 1$ & 1.0 & $2 / 1$ & 1.0 & $2 / 1$ & 0.173 \\
\hline Mononuclear infiltrate & 1.5 & $2 / 1$ & 1.5 & $2 / 1$ & 1.0 & $2 / 1$ & 1.0 & $2 / 1$ & 0.860 \\
\hline $\begin{array}{c}\text { Polymorphonuclear } \\
\text { infiltrate }\end{array}$ & 0.0 & $0 / 0$ & 0.0 & $1 / 0$ & 0.0 & $2 / 0$ & 0.0 & $0 / 0$ & 0.444 \\
\hline Neovascularization & 1.0 & $2 / 1$ & 1.0 & $2 / 1$ & 1.0 & $2 / 1$ & 1.0 & $1 / 1$ & 0.206 \\
\hline Abscess & 0.0 & 00 & 0.0 & $0 / 0$ & 0.0 & $1 / 0$ & 0.0 & 00 & 1.000 \\
\hline Bacterial colony & 0.0 & $0 / 0$ & 0.0 & $0 / 0$ & 0.0 & $0 / 0$ & 0.0 & $0 / 0$ & 1.000 \\
\hline Foreign body & 1.0 & $1 / 1$ & 1.0 & $1 / 1$ & 1.0 & $1 / 0$ & 1.0 & 11 & 0.231 \\
\hline
\end{tabular}

$\mathrm{EI}=$ pneumoperitoneum for 30 minutes before laparotomy; $\mathrm{EII}=$ pneumoperitoneum for 30 minutes after abdominal closure; EIII = pneumoperitoneum for 30 minutes before laparotomy and 30 minutes after abdominal closure; $\mathrm{C}=$ control group, without pneumoperitoneum. 
reflect interference in some stage of the wound healing process. The first stage of healing involves hemostasis and inflammation and may be affected mainly by anti-inflammatory agents, among others, which may reduce the tensile strength of the abdominal wall due to reduced collagen formation. As a result, higher rates of wound dehiscence, incisional hernia, and weight loss may be observed $^{14,15}$.

The normal wound healing process consists of three successive and overlapping phases: 1) exudation or acute inflammatory response, occurring mainly from day 1 to $4 ; 2$ ) proliferation or fibroplasia, from day 4 to 14 ; and 3) collagen maturation or remodeling, often beginning on day 10 and extending through day $180^{9,14-16}$. Throughout the three phases, the scar tissue is arranged so that progressive collagen formation and remodeling can be observed ${ }^{9-12,16}$

$\mathrm{CO}_{2}$ pneumoperitoneum has been reported to induce a decrease in the amount of type I and II collagen 10 days postoperatively in a dorsal wound. However, in the same period, the use of helium to create the pneumoperitoneum has been shown to increase collagen synthesis ${ }^{10,12}$.

It remains uncertain how $\mathrm{CO}_{2}$ pneumoperitoneum may affect the healing process in the abdominal wall. It has been suggested that $\mathrm{CO}_{2}$ pneumoperitoneum may affect tensile strength, because a decrease in $\mathrm{pH}$ is observed in the subcutaneous, intraarterial, and intra-abdominal tissue after the creation of a $\mathrm{CO}_{2}$ pneumoperitoneum, a fact that leads to suppression of cellular differentiation of lineages derived from monocytes (which have a role in healing), thus altering collagen formation locally and systemically ${ }^{10,12,17}$.

However, in the present study, histopathological and biomechanical data evaluated 7 and 14 days postoperatively substantiate the hypothesis that $\mathrm{CO}_{2}$ pneumoperitoneum at a pressure corresponding to that used in laparoscopic surgical procedures in humans does not affect abdominal wall wound healing. This result is in agreement with previous studies reporting that $\mathrm{CO}_{2}$ pneumoperitoneum and laparotomy had no systemic influence on wound healing, since no influence was observed in dorsal wound repair in rats ${ }^{18,19}$.

Potential effects of chemical and cellular magnitude, such as those observed in metalloproteinases or peritoneal macrophage concentration, can be regarded as minimal, thus failing to promote changes in the criteria analyzed and, consequently, failing to present important clinical significance $\mathrm{e}^{4,8,10,12,17}$.

Similarly, $\mathrm{CO}_{2}$ pneumoperitoneum at a pressure of 5 $\mathrm{mmHg}$ may induce only transient effects on the healing process in the abdomen, as observed in other organs, and such effects may therefore not be detectable after 7 or 14 days ${ }^{3,5}$.

\section{Conclusion}

Under the present experimental conditions, $\mathrm{CO}_{2}$ pneumoperitoneum did not interfere with abdominal wall wound healing.

\section{References}

1. Forbes SS, Eskicioglu C, McLeod RS, Okrainec A. Meta-analysis of randomized controlled trials comparing open and laparoscopic ventral and incisional hernia repair with mesh. Br J Surg. 2009;96:851-8.

2. McGreevy JM, Goodney PP, Birkmeyer CM, Finlayson SRG, Laycock WS, Birkmeyer JD. A prospective study comparing the complication rates between laparoscopic and open ventral hernia repairs. Surg Endosc. 2003;17:1778-80.

3. Gutta CN, Oniub T, Mehrabia A, Schemmera P, Kashfi A, Krausa T, Büchlera MW. Cardiopulmonary physiology and pathophysiology as consequence of laparoscopic surgery. Dig Surg. 2004;21:95-105.

4. Amin AT, Shiraishi N, Ninomiya S, Tajima S, Inomata M, Kitano $\mathrm{S}$. Activation of nuclear factor kappa $\mathrm{B}$ and induction of migration inhibitory factor in tumors by surgical stress of laparotomy versus carbon dioxide pneumoperitoneum: an animal experiment. Surg Endosc. 2010;24:578-83.

5. Sharma KC, Brandstetter RD, Brensilver JM, Jung LD. Circulatory and respiratory complications of carbon dioxide insufflation. Chest. 1996;110:810-5.

6. Eklund A, Carlsson P, Rosenblad A, Montgomery A, Bergkvist L, Rudberg C. Long-term cost-minimization analysis comparing laparoscopic with open (Lichtenstein) inguinal hernia repair. Br J Surg. 2010;97:765-71.

7. Avital S, Itah R, Szomstein S. Correlation of $\mathrm{CO} 2$ Pneumoperitoneum pressures between rodents and humans. Surg Endosc. 2009;23:50-4.

8. Mastboom W, Hendricks T, Deman B, De Boer HH. Influence of methylprednisolone on the healing of intestinal anastomoses in rats. Br J Surg. 1991;78:54-6.

9. Tognini JRF, Fagundes DJ, Novo NF, Juliano Y. Biomechanical and morphological study in rats' abdominal wall healing under meloxicam action. Acta Cir Bras. 2000;15(3):146-55.

10. Rosch R, Junge K, Binnebösel M, Mirgartz N, Klinge U, Schumpelick $\mathrm{V}$. Gas-related impact of pneumoperitoneum on systemic wound healing. Langenbecks Arch Surg. 2008;393:75-80.

11. Watanabe ALC, Watanabe LM. Effects of tenoxicam on the abdominal wall healing: experimental study in rats. Acta Cir Bras. 2005;20(2):140-3.

12. Rosch R, Junge $K$, Binnebosel $M$, Mirgartz $N$, Klinge $U$, Schumpelick V. Improved abdominal wall wound healing by helium pneumoperitoneum. Surg Endosc. 2006;20:1892-6.

13. Rossi LF, Ramos RR, Ely JB, Kestering DM, Soldi MS, Brum SPB, d'Acampora AJ. Considerations that may influence the result of trials assessing tensile strength in experimental surgery. Acta Cir Bras. 2007;22(6):499-502.

14. Lopes JV, Freitas LAM, Marques RD, Bocca AL, Sousa JB, Oliveira PG. Analysis of the tensile strength on the healing of the abdominal wall of rats treated with infliximab. Acta Cir Bras. 2008;23(5):4416.

15. Minossi JG, Leite CVS, Naresse LE, Rodrigues MAM, Angeleli AYO, KobayasiS. Sodium diclofenac effect in abdominal wall 
cicatrization in rats: histological, breaking strength and tissue collagen studies. Acta Cir Bras. 2001;16(3):146-54.

16. Guo S, DiPietro LA. Factors affecting wound healing. J Dent Res. 2010;89:219-29.

17. Neuhaus SJ, Watson DI. Pneumoperitoneum and peritoneal surface changes: a review. Surg Endosc. 2004;18(9):1316-22.

18. Wickens JC, Whelan RL, Allendorf JDF, Donahue J, Buxton E, McKee A, Panageas K, Gleason N, Lee S, Bessle M. Wound tensile strength and contraction rate are not affected by laparotomy or pneumoperitoneum. Surg Endosc. 1998;12:1166-70.

19. Agalar F, Hamaloglu E, Daphan C, Tarim A, Onur R, Renda N, Sayek I. Effects of $\mathrm{CO} 2$ insufflation and laparotomy on wound healing in mice. Aust N Z J Surg. 2000;70:739-42.

\section{Correspondence:}

João Batista de Sousa

Campus Universitário Darcy Ribeiro

Prédio da Reitoria, $2^{\circ}$ pavimento, sala B2-16

70910-900 Brasília - DF Brasil

Tel.: (55 61)3307-2201

sousajb@unb.br

Received: August 10, 2011

Review: October 14, 2011

Accepted: November 16, 2011

Conflict of interest: none

Financial source: none

${ }^{1}$ Research performed at the Laboratory of Experimental Surgery, Medical School, University of Brasilia (UnB), Brazil. 